bioRxiv preprint doi: https://doi.org/10.1101/2021.04.16.440162; this version posted April 16, 2021. The copyright holder for this preprint (which was not certified by peer review) is the author/funder, who has granted bioRxiv a license to display the preprint in perpetuity. It is made available under aCC-BY-NC-ND 4.0 International license.

\title{
TDP-43 regulates GAD1 mRNA splicing and GABA signaling in Drosophila brains
}

Giulia Romano*, Nikola Holodkov, Raffaella Klima and Fabian Feiguin*.

International Centre for Genetic Engineering and Biotechnology (ICGEB), Padriciano 99, 34149 Trieste, Italy.

*Correspondence to: giulia.romano@icgeb.org or fabian.feiguin@icgeb.org

Phone: +39-040-3757201

Fax: +39-040-226555 
bioRxiv preprint doi: https://doi org/10.1101/2021.04.16.440162; this version posted April 16, 2021. The copyright holder for this preprint (which was not certified by peer review) is the author/funder, who has granted bioRxiv a license to display the preprint in perpetuity. It is made available under aCC-BY-NC-ND 4.0 International license.

\begin{abstract}
Alterations in the function of the RNA-binding protein TDP-43 is largely associated with the pathogenesis of amyotrophic lateral sclerosis (ALS), a devastating disease of the human motor system that leads to motoneurons degeneration and reduced life expectancy by molecular mechanisms not well known. Regarding to that, we found that the expression levels of the glutamic acid decarboxylase enzyme (GAD1), responsible to convert glutamate to $\gamma$-aminobutyric acid (GABA), were downregulated in TBPH-null flies and motoneurons derived from ALS patients carrying mutations in TDP-43 suggesting that defects in the regulation of GAD1 may lead to neurodegeneration by affecting neurotransmitter balance. In this study, we observed that TBPH was required to regulate GAD1 pre-mRNA splicing and GABA levels in Drosophila brains. Interestingly, we discovered that pharmacological treatments aimed to modulate GABA neurotransmission were able to revert locomotion deficiencies in TBPH-minus flies revealing novel mechanisms and therapeutic strategies in ALS.
\end{abstract}

Keywords: GAD1 / GABA / TDP-43 / ALS / Drosophila. 
bioRxiv preprint doi: https://doi.org/10.1101/2021.04.16.440162; this version posted April 16, 2021. The copyright holder for this preprint (which was not certified by peer review) is the author/funder, who has granted bioRxiv a license to display the preprint in perpetuity. It is made available under aCC-BY-NC-ND 4.0 International license.

\section{INTRODUCTION}

A common characteristic shared by several neurodegenerative diseases is the dysfunction of the RNA-binding protein TDP-43, a member of the heterogenous nuclear ribonucleoproteins (hnRNPs) family (Cook et al., 2008; de Boer et al., 2021). Initially identified as the main component of the ubiquitinated cytoplasmic inclusions in ALS and frontotemporal lobar degeneration (FTLD) (Arai et al., 2006; Geser et al., 2009; Neumann et al., 2006), TDP-43 pathology is currently described in a large proportion of cases of Alzheimer's disease as well as Parkinson's and Huntington's disease (Amador-Ortiz et al., 2007; Higashi et al., 2007; Josephs et al., 2014; Schwab et al., 2008). Attentive studies aimed to understand the normal function of TDP-43 and its participation in the mechanisms of neurodegeneration have, therefore, became critical to establish the metabolic pathways implicated in TDP-43-mediated neuronal toxicity. In this direction we have previously indicated that TDP-43 is required to regulate the synaptic levels of GAD1, the enzyme responsible to convert glutamate to $\gamma$-aminobutyric acid (GABA), suggesting that modifications in the glutamate/GABA neurotransmitter balance may affect neuronal survival in TDP-43 perturbed brains (Romano et al., 2018). If the involvement of glutamate in the pathogenesis of ALS disease was already suggested by several studies (Foran and Trotti, 2009; Trotti et al., 2001; Van Den Bosch et al., 2006), GABA implications are less known. Consequently, in this study we investigated the mechanisms by which TDP-43 regulates the cytoplasmic levels of GAD1 and determined the role of GABA neurotransmission in TDP-43 disease using Drosophila.

\section{MATERIALS and METHODS}

\section{Fly strains}

The fly genotypes used for the experiments are indicated hereafter:

$\mathrm{w}^{1118}$ - OregonR - w;tbph ${ }^{\Delta 23} / \mathrm{CyO}^{\mathrm{GFP}}-\mathrm{w} ; \mathrm{tbph}^{\Delta 142} / \mathrm{CyO}^{\mathrm{GFP}}-\mathrm{w} ;$ elav-GAL4/CyO ${ }^{\mathrm{GFP}}$ - w,UAS-Dicer2;elavGAL4/CyO GFP - w;siRNA-UAS-GFP (\#9330, BDSC) - w;UAS-GAD1/TM3,Sb (gifted from Dr. Andreas Prokop) - w;UAS-TBPH — w;UAS-TBPH-RNAi/TM6B (\#38377, VDRC) - siRNA-GABAA receptor, resistant to dieldrin (RDL, \#41101, \#100429, VDRC) - siRNA Ligand Gated Chloride Channel (LCCH3, \#37409, \#109606, VDRC) - siRNA Glycine like receptor (GRD, \#38384, \#58175) - siRNA Vesicular GABA Transporter (vGAT, \#45916, VDRC) - siRNA-GABA Receptor Type 1 (R1, \#101440, VDRC) - siRNA-GABAB receptor Type 2 (R2,\#1784,\#1785,\#110268, VDRC) - siRNA-GABA receptor Type 3 (R3, \#50622, \#108036, VDRC).

\section{Climbing assay}

Freshly eclosed flies were transferred in new food vials and let to adapt for 3 to 4 days. After this period, they were moved, without anesthesia, to $15 \mathrm{ml}$ glass cylinders, tapped to the bottom and let climb taking advantage of their natural drive for negative geotaxis. The number of flies that reached the top of the tube in $15 \mathrm{~s}$ was counted, and converted in percentage.

\section{Larval Brain, Microscope Acquisition and Quantification}

Larvae were selected and dissected as previously described in (Romano et al., 2014). Briefly, for whole larval brain staining, previously selected larvae were dissected on Sylgard plates in Phosphate Buffer (PB), brains were removed and fixed 20 min in 4\% formaldehyde in Phosphate Buffer with 0.3\% Triton X100 (PBT), blocked in 
bioRxiv preprint doi: https://doi.org/10.1101/2021.04.16.440162; this version posted April 16, 2021. The copyright holder for this preprint (which was not certified by peer review) is the author/funder, who has granted bioRxiv a license to display the preprint in perpetuity. It is made available under aCC-BY-NC-ND 4.0 International license.

5\% Normal Goat Serum (NGS), labelled with primary and secondary antibodies and mounted on microscope slides in Slow Fade (S36936, Thermofisher). Brain images were acquired on 20x at a 0.6-fold magnification on a LSM 880 Zeiss confocal microscope and then analyzed using ImageJ. Z-stacking was performed and the ratio of GABA/Elav Max Intensity was calculated. Primary antibodies concentration: anti-Elav (1:250, DSHB), antiGABA (1:500, Sigma). Secondary antibodies concentration: Alexa Fluor 488 (1:500, Life Technologies), Alexa Fluor 555 (1:500, Life Technologies).

\section{Cell culture and RNA interference}

S2 cells were cultured in Insect-Xpress medium (Lonza) supplemented 10\% fetal bovine serum and 1X antibioticantimycotic solution (\#A5955, Sigma). RNA interference was achieved using HiPerfect Transfection Reagent (\#301705, Qiagen) and siRNA specific for Drosophila TBPH (5'-GGAAGACCACAGAGGAGAGC-3'), as control siRNA for luciferase was used (5'-UAAGGCUAUGAAGAGAUAC-3'; Sigma). Immediately before transfection $2 \times 10^{6}$ cells were seeded in 6 -well plates in $1.4 \mathrm{ml}$ of medium containing $10 \%$ fetal serum. $2 \mu \mathrm{g}$ of each siRNA, were added to $91 \mu 1$ of Opti-MEM I reduced serum medium (\#51985-026, Thermo Fisher Scientific), incubated 5 minutes at room temperature and subsequently $6 \mu 1$ of HiPerfect Transfection Reagent were added. The silencing procedure was performed again after 24 hours. Plasmid containing the Gad1 mini-gene and Gal4 were co-transfected $(0,3 \mu \mathrm{g}$ each) at 24 hours together with the second siRNA dose. Cells were analyzed after 72 hours of the initial treatment.

\section{GAD1 minigene construction}

A mini-gene containing the 5' UTR region of Gad1 spanning from exon1 to exon2 (ref isoform FBtr0073276) in frame with a reporter EGFP has been cloned in pUAST attB plasmid. The minigene was co-transfected with pGAL4 in S2 cells. The EGFP expression was analyzed in S2 cells treated with siRNAs against TDP-43 or luciferase.

\section{RT-PCR}

Adult heads were mechanically squeezed to proceed with RNA extraction, using RNeasy®Microarray tissue kit (\#73304 Qiagen) and treated with Turbo DNA-free kit (\#AM1907 Ambion). Retro-transcription was performed using oligo-dT primers and SuperScript ${ }^{\circledR}$ III First-Strand Synthesis (\#18080093 Invitrogen). Gene specific primers were designed for amplification:

Gad1(intronic set): 5 'GCCAAACTCCGCATTCCATTT3' and 5'ACCGAAGGCCGTGGGTCCTCG3'

Gad1(exon/exon set): 5'TGATCCTTGAACCGGAGTGC3' and 5'ACCATCAGCGTTCCCTTCTG3'

Rpl11 5'CCATCGGTATCTATGGTCTGGA3' and 5'CATCGTATTTCTGCTGGAACCA3'

The quantification was calculated according the $\Delta \Delta \mathrm{C}_{\mathrm{T}}$ equation and then normalized on control genotype.

\section{Western Blot}

$\mathrm{S} 2$ cells were lysed in lysis buffer (10mM Tris, $150 \mathrm{mM} \mathrm{NaCl}, 5 \mathrm{mM}$ EDTA, $5 \mathrm{mM}$ EGTA, 10\% Glycerol, 50 $\mathrm{mM} \mathrm{NaF}, 5 \mathrm{mM}$ DTT, $4 \mathrm{M}$ Urea, pH 7.4, protease inhibitors (Roche, \#11836170001)) and after protein quantification of lysates by Qbit (Q\#33211, Invitrogen), samples were separated on 10\% SDS-PAGE and transfer 
bioRxiv preprint doi: https://doi.org/10.1101/2021.04 16.440162; this version posted April 16, 2021. The copyright holder for this preprint (which was not certified by peer review) is the author/funder, who has granted bioRxiv a license to display the preprint in perpetuity. It is made available under aCC-BY-NC-ND 4.0 International license.

to $0,22 \mu \mathrm{m}$ nitrocellulose membranes (\#NBA083C Whatman Protran). Membranes were blocked in 5\% non-fat dry milk in Tris Buffered Saline with $0.1 \%$ Tween-20 (TBS-T). Primary antibodies were used with the following concentrations: anti-GFP (1:2000, Invitrogen), anti-TBPH (1:3000, homemade (Feiguin et al., 2009) and anti tubulin DM1A (1:5000, Calbiochem). Secondary antibodies concentration: anti-rabbit HRP conjugated (1:10000, Pierce \#32460), anti-mouse HRP conjugated (1:10000, Pierce \# 32430). For detection, SuperSignal ${ }^{\mathrm{TM}}$ West Femto Maximum Sensitivity Substrate Kit (Pierce, \#PR34095) was used. Quantification was performed by ImageJ after acquisition of the autoradiographic films with an Epson Expression 1680 Pro Scanner.

\section{Drug treatment.}

Muscimol $100 \mu \mathrm{M}$ and Nipecotic Acid $200 \mu \mathrm{M}$ were used. According to the final concentration needed, drugs were prepared and diluted in the fresh fly food. This solution was aliquoted fly tubes where parental flies were transferred and let lay embryos for a period of $24 \mathrm{~h}$. After this period, parental flies were discarded, and embryos were let to grow to third instar larvae, used for further analysis.

\section{Larval movement.}

Third instar larvae were individually selected, cleaned with water from any food remaining and placed on $0.7 \%$ agarose plates under stereoscope vision. After $30 \mathrm{~s}$ of adaptation, the number of peristaltic waves performed in 2 min were counted.

\section{Statistical Analysis.}

All statistical analysis was performed with GraphPad Prism 7.0 applying one-way ANOVA test (Bonferroni post-test).

\section{RESULTS}

Drosophila TDP-43 regulates the expression levels of GAD1 by facilitating its pre-mRNA splicing.

We have previously demonstrated that the protein levels of GAD1 appeared downregulated in TBPH-null flies, however, the mechanisms behind these modifications were not identified (Romano et al., 2018). In order to address this question, and considering that TBPH is involved in the regulation of different aspects of the RNA metabolism, we decided to investigate whether the GAD1 RNA splicing was affected in TBPH-minus alleles. To this purpose, we designed a set of primers specific to discriminate GAD1 pre m-RNA and another one specific for m-RNA (respectively the intronic set and the exonic set, (see Fig.1B), and quantified their expression levels by qRT-PCR. Interestingly, we found that the pre-mRNA of GAD1 appeared upregulated in the brains of the TBPH-mutant alleles compared to controls (Fig.1B, left graph). On the contrary, the mature mRNA transcript of GAD1 was downregulated in the mutant flies judged against controls (Fig.1B, right graph) indicating that TBPH is required to regulate the processing of GAD1 mRNA, most probably, through the splicing of the mature transcript in Drosophila brains. In agreement with this possibility, we observed the presence of putative binding sites for TBPH in the long intron present at the 5'UTR region of GAD1, between the non-coding exon1 and the coding exon2 (Fig.1C, upper scheme). In order to test if the absence of TBPH influenced the processing of these segments, we constructed a minigene containing the genomic sequences described above (Fig.1C, upper left 
bioRxiv preprint doi: https://doi.org/10.1101/2021.04.16.440162; this version posted April 16, 2021. The copyright holder for this preprint (which was not certified by peer review) is the author/funder, who has granted bioRxiv a license to display the preprint in perpetuity. It is made available under aCC-BY-NC-ND 4.0 International license.

scheme). The GAD1 pre-mRNA 5'-UTR minigene also presented an EGFP cloned in frame with the second exon of GAD1 that carried the original ATG starting codon. The construct was placed under the control of the GAL4UAS system and used to transfect Drosophila S2 cells under the Actin promoter (actin-GAL4). Thus, S2 cells cotransfected with an RNAi against TBPH showed a strong reduction in the expression of the EGFP protein compared to control cells treated with an RNAi against luciferase in western blot assays (Fig.1C right panel, quantified in the left graph). These results show that TBPH function is required for the proper splicing and expression of the GAD1 pre-mRNA 5'-UTR minigene and strongly suggest that similar alterations may explain the defects detected in the processing of the immature GAD1 mRNA in TBPH-null flies.
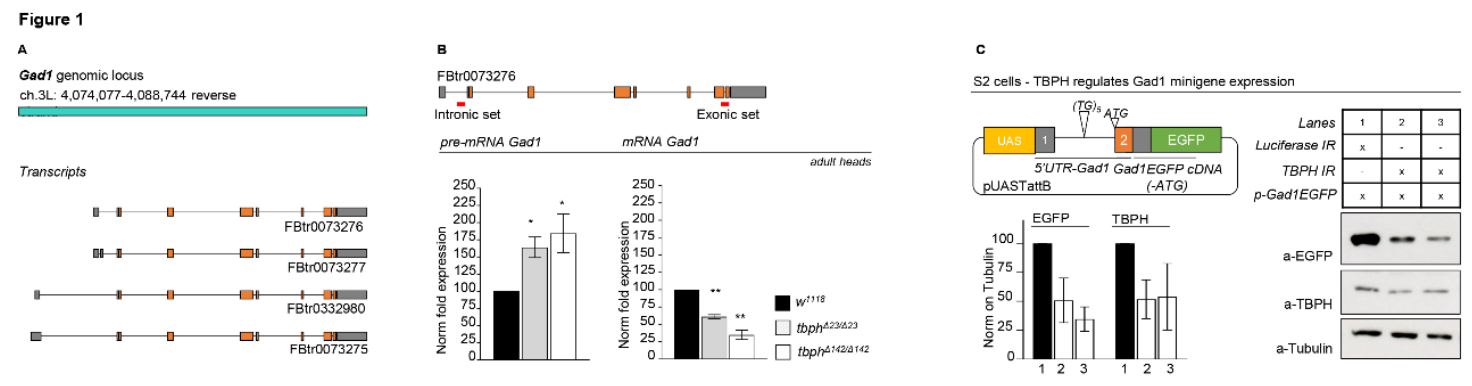

Figure 1. TBPH modulates GAD1 protein expression by regulating its pre-mRNA 5'-UTR splicing. A Scheme of Gad1 genomic locus and transcripts in Drosophila. B qRT-PCR of Gad1 pre-mRNA left panel and mRNA right panel on adult heads of $\mathrm{w}^{1118}, \mathrm{tbph}^{\Delta 23 / \Delta 23}$ and $\operatorname{tbph}^{\Delta 142 / \Delta 142} . n=3 ; * \mathrm{p}<0.05$ and $* * \mathrm{p}<0.01$ calculated by one-way Anova. C Western blot analysis for GAD1 minigene expression in S2 cells (anti-EGFP, anti-TBPH, and anti-Tubulin). Lane 1: S2 cells co-transfected with GAD1 minigene, Actin-GAL4 and Luciferase-IR. Lanes 2 and 3: S2 cells co-transfected with GAD1 minigene, Actin-GAL4, and TBPH-IR. In the graph the quantification of EGFP and TBPH expression weighted on Tubulin of Luciferase-IR (black column) compared with TBPH-IR (white columns). In the scheme GAD1 minigene: the 5' UTR region of Gad1 spanning from exon1 to exon2 in frame with a reporter EGFP has been cloned in pUAST attB plasmid. $n=2$, Error bars SEM.

\section{Reduced levels of GABA neurotransmitter in TDP-43-null brains affect locomotive behaviors}

The alterations in the processing of GAD1 immature mRNA described above insinuate that GABA neurotransmission might be affected in TBPH-null flies. In fact, the synthesis of GABA occurs through the conversion of glutamate by GAD1 enzyme; then GABA is loaded into vesicles by the vesicular GABA transporter (vGAT) (Owens and Kriegstein, 2002). The released GABA in the synaptic cleft is bind by GABA receptors placed on the post synaptic cell. The GABA receptors are divided into two types: the ionotropic and the metabotropic. To date in Drosophila three ionotropic subunits and three metabotropic subunits have been described (see Table 1). In order to address this hypothesis, we decided to test whether modifications in GABA signaling were able to influence the locomotive phenotypes described in TBPH deficient flies. For these experiments, we took advantage of the GAL4-UAS expression system to simultaneously co-silence the endogenous TBPH protein together with the various GABA ionotropic and metabotropic receptors.

\begin{tabular}{|l|l|l|l|l|l|}
\hline $\begin{array}{l}\text { Drosophila GABA } \\
\text { receptor/transporter }\end{array}$ & $\begin{array}{l}\text { Gene } \\
\text { CG }\end{array}$ & Classification & RNAi fly & $\begin{array}{l}\text { Human } \\
\text { ortholog }\end{array}$ & Reference \\
\hline $\begin{array}{l}\text { RDL } \\
\text { (resistant to dieldrin) }\end{array}$ & 10537 & $\begin{array}{l}\text { GABA }_{A} \\
\text { Ionotropic }\end{array}$ & $\begin{array}{l}\# 41101 \text { (VDRC) } \\
\# 100429 \text { (VDRC) }\end{array}$ & GABRP & $\begin{array}{l}\text { (Buckingham et al., 1994; } \\
\text { Ffrench-Constant et al., } \\
1991)\end{array}$ \\
\hline $\begin{array}{l}\text { LCCH3 } \\
\text { (ligand-gated chloride } \\
\text { channel homolog 3) }\end{array}$ & 17336 & $\begin{array}{l}\text { GABA } \\
\text { Ionotropic }\end{array}$ & $\begin{array}{l}\# 37409 \text { (VDRC) } \\
\# 109606 \text { (VDRC) }\end{array}$ & GABRB1 & (Gisselmann et al., 2004; \\
Harvey et al., 1994)
\end{tabular}


bioRxiv preprint doi: https://doi.org/10.1101/2021.04.16.440162; this version posted April 16, 2021. The copyright holder for this preprint (which was not certified by peer review) is the author/funder, who has granted bioRxiv a license to display the preprint in perpetuity. It is made available under aCC-BY-NC-ND 4.0 International license.

\begin{tabular}{|c|c|c|c|c|c|}
\hline $\begin{array}{l}\text { GRD } \\
\text { (gaba receptor/glycine } \\
\text { receptor) }\end{array}$ & 7446 & $\begin{array}{l}\mathrm{GABA}_{\mathrm{A}} \\
\text { Ionotropic }\end{array}$ & $\begin{array}{l}\# 38384 \text { (VDRC) } \\
\# 58175 \text { (VDRC) }\end{array}$ & GABRA4 & $\begin{array}{l}\text { (Gisselmann et al., 2004; } \\
\text { Henderson et al., 1993) }\end{array}$ \\
\hline $\begin{array}{l}\text { GABA-B-R1 } \\
\text { (gaba-b receptor subtype 1) }\end{array}$ & 15274 & $\begin{array}{l}\mathrm{GABA}_{\mathrm{B}} \\
\text { Metabotropic }\end{array}$ & $\# 101440$ (VDRC) & GABBR1 & (Mezler et al., 2001) \\
\hline $\begin{array}{l}\text { GABA-B-R2 } \\
\text { (gaba-b receptor subtype 2) }\end{array}$ & 6706 & $\begin{array}{l}\mathrm{GABA}_{\mathrm{B}} \\
\text { Metabotropic }\end{array}$ & $\begin{array}{l}\# 1784 \text { (VDRC) } \\
\# 1785 \text { (VDRC) } \\
\# 110268 \text { (VDRC) }\end{array}$ & GABBR2 & (Mezler et al., 2001) \\
\hline $\begin{array}{l}\text { GABA-B-R3 } \\
\text { (gaba-b receptor subtype 3) }\end{array}$ & 3022 & $\begin{array}{l}\mathrm{GABA}_{\mathrm{B}} \\
\text { Metabotropic }\end{array}$ & $\begin{array}{l}\# 50622 \text { (VDRC) } \\
\# 108036 \text { (VDRC) }\end{array}$ & GABBR2 & (Mezler et al., 2001) \\
\hline $\begin{array}{l}\text { vGAT } \\
\text { (vesicular gaba } \\
\text { transporter) }\end{array}$ & 8394 & $\begin{array}{l}\text { Vesicular } \\
\text { transporter }\end{array}$ & \#45916 (VDRC) & SLC32A1 & $\begin{array}{l}\text { (Fei et al., 2010; Gasnier, } \\
\text { 2004) }\end{array}$ \\
\hline
\end{tabular}

Thus, specific RNAi against the GABA $A_{A}$ type receptor (RDL), the ligand-gated chloride channel (LCCH3), the $\mathrm{GABA}_{B}$ type receptor 1, 2 and 3 (R1, R2 and R3) were expressed, either alone or together with an RNAi against TBPH, under the neuronal driver elav-GAL4. As a result, we found that the suppression of the GABA receptors strongly enhanced the motility problems present in TBPH-defective flies compared to control insects expressing the RNAi against the GABA receptors alone (Fig. 2 and Supplementary Figure 1). 


\section{Figure 2}

A

RDL

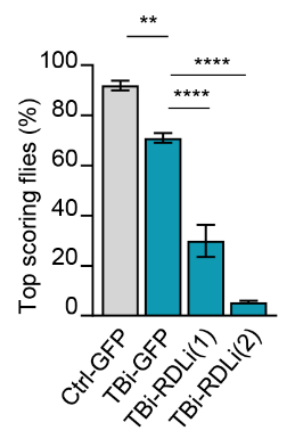

E

GABA-R1

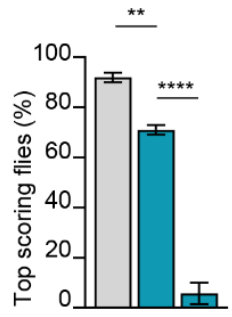

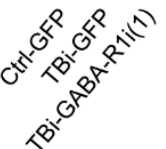

B

$\underline{\mathrm{LCCH}} 3$

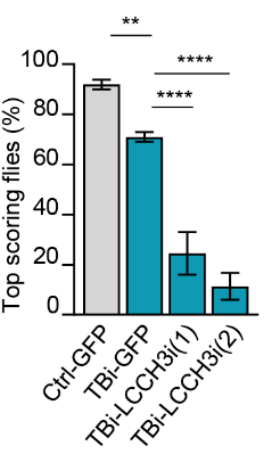

F

GABA-R2
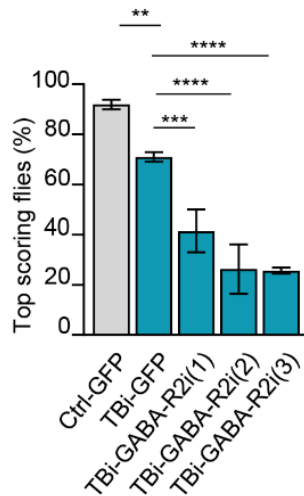

c

GRD

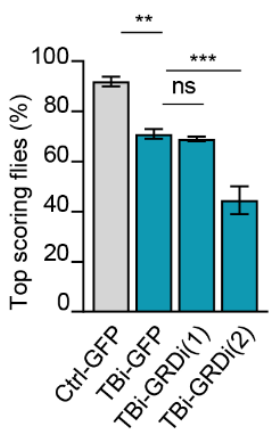

G

GABA-R3
D

vGAT

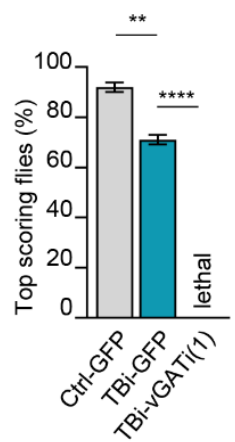

Ctrl background

Tbi background

Figure 2. Silencing of GABA receptors and transporter worsen the TBPH hypomorphic phenotype. A-G Climbing assay of 4 days adult flies of control (Ctrl-GFP=tbph ${ }^{\Delta 23}$, elav-GAL4/UAS-GFP;UAS-Dicer/+), TBPH hypomorphic (TBi-GFP= $\operatorname{tbph}^{\Delta 23}$, elav-GAL4/UASGFP;UAS-Dicer/UAS-TBPH-IR) and TBPH hypomorphic with several GABA receptors silenced (TBi-GABA receptors name $=\mathrm{tbph}^{\Delta 23}$, elavGAL4/UAS-GABA-receptor IR;UAS-Dicer/UAS-TBPH-IR). In A RDL-IR line (1)= \#41101, line (2) \#100429; in B LCCH3-IR line (1) \#37409, line (2) \#109606; in C GRD-IR line (1) \#38384, line (2) \#58175; in D vGAT-IR line (1) \#45916; in $\mathbf{E}$ GABA receptor type 1 line (1) \#101440; in $\mathbf{F} \mathrm{GABA}_{B}$ receptor type 2 line (1) \#1784, line (2) \#1785, line (3) \#110268; in G GABA receptor type 3 line (1) \#50622, line (2) \#108036. The total number of tested animals per genotype was $>50 . n s=$ not significative, $* \mathrm{p}<0.05, * * \mathrm{p}<0.01, * * * \mathrm{p}<0.001$ and ****p<0.0001; calculated by one-way ANOVA. Error bars SEM.

In the same direction, we utilized a specific antibody against GABA to quantify the intracellular levels of the neurotransmitter in third instar larval brain. After the staining, we found that the levels of GABA intensity appeared significantly reduced in TDP-43-null brains compared to wild type controls (Fig. 3A-B, E). Interestingly, we found that the neuronal transgenic expression of GAD1 or the endogenous protein TBPH in TDP-43-minus 
bioRxiv preprint doi: https://doi.org/10.1101/2021.04.16.440162; this version posted April 16, 2021. The copyright holder for this preprint (which was not certified by peer review) is the author/funder, who has granted bioRxiv a license to display the preprint in perpetuity. It is made available under aCC-BY-NC-ND 4.0 International license.

backgrounds were able to recover the expression levels of GABA in Drosophila brains (Fig. 3C-D, E), indicating that these results are specific and the regulation of GAD1 levels is critical to prevent GABA neurotransmission defects and neurodegeneration in TDP-43-defective brains.

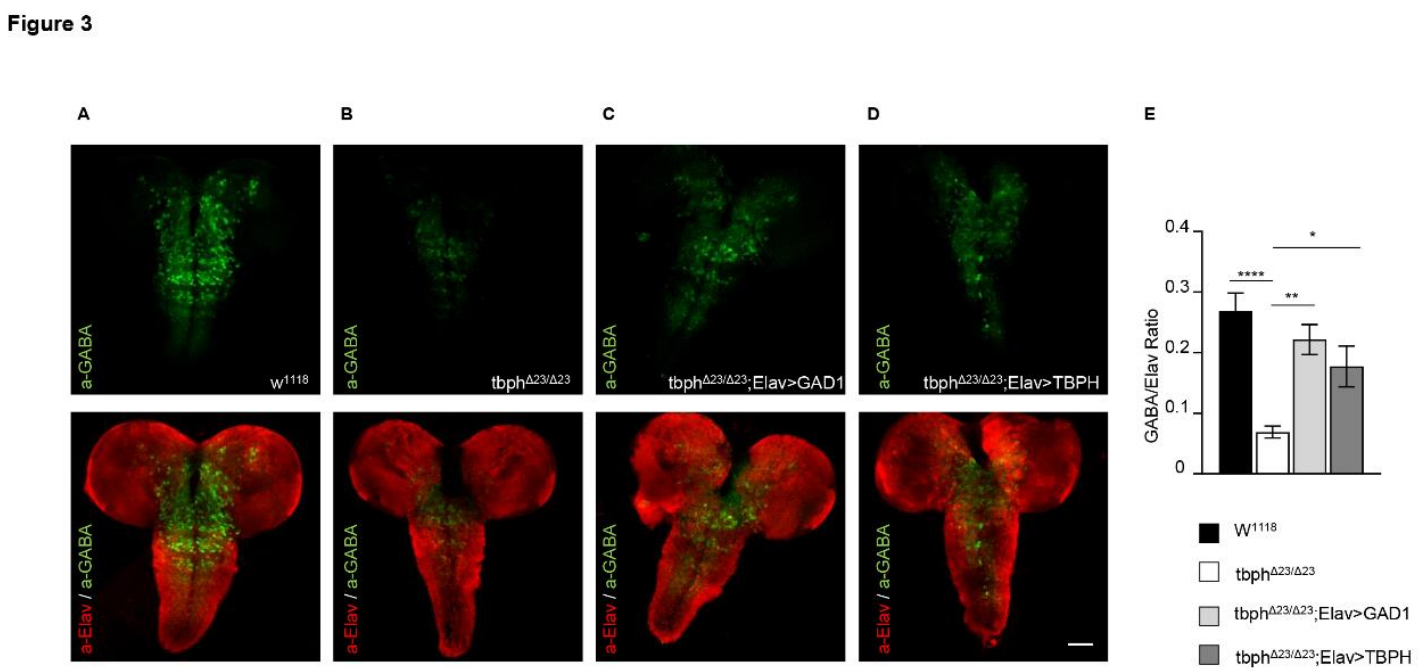

Figure 3. GABA was strongly downregulated in TBPH minus larval brains and recovered by GAD1 and TBPH expression in neurons. A-D Confocal microscopy acquisition of whole larval brains. GABA neurotransmitter was labeled with anti-GABA (Green) and neurons were

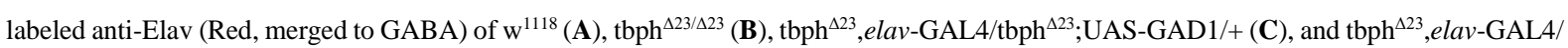
$\operatorname{tbph}^{\Lambda 23}$, UAS-TBPH (D). E Quantification of whole brain intensity GABA/Elav ratio. The number of examined brains per genotype was $>10$. $* \mathrm{p}<0.05, * * \mathrm{p}<0.01, * * * * \mathrm{p}<0.0001$ calculated by one-way ANOVA. Error bars SEM. Scale bar: $50 \mu \mathrm{m}$.

\section{The recovery of GABA neurotransmission improves locomotion in TDP-43-null flies}

In order to determine if the reduced levels of GABA detected in TBPH-minus brains were related with the neurodegenerative phenotypes described in these flies, we decided to treat TBPH-null flies with different agonists of GABA neurotransmission. For these assays, a potent GABA uptake inhibitor, Nipecotic acid (200 $\mu$ M) was added to the fly food during larvae development and found that the administration of this compound was able to consistently improve the peristaltic movements of the TBPH-minus third-instar larvae (L3) compared to untreated mutants or wild-type controls (Fig. 4A).

The positive effect of this pharmacological treatment became more obvious when TBPH hypomorphic background was utilized. As a matter of fact, we found that $200 \mu \mathrm{M}$ of Nipecotic Acid dispensed to flies expressing TBPH-RNAi in neurons (UAS-Dcr-2/+;tbph ${ }^{\Delta 23}$, elav-GAL4/+;TBPH-RNAi/+) were sufficient to recover motility (Fig. 4B), indicating that GABA neurotransmission plays an important role in TBPH-mediated neurodegeneration. Similar approach utilizing a different drug, the Muscimol $(100 \mu \mathrm{M})\left(\mathrm{a}\right.$ known $\mathrm{GABA}_{\mathrm{A}}$ receptor agonist) showed a significative rescue of L3 larvae motility in TBPH hypomorphic background-null alleles compared to controls (Fig. 4C). 


\section{Figure 4}

A
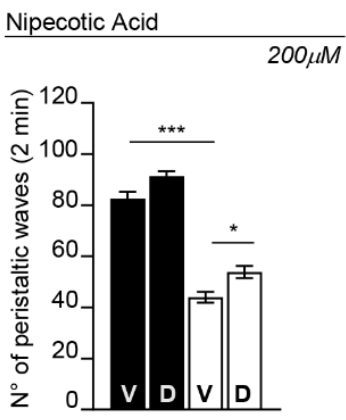

B
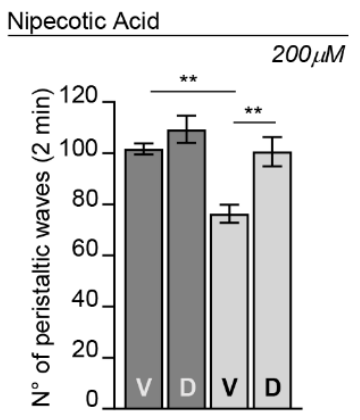

C

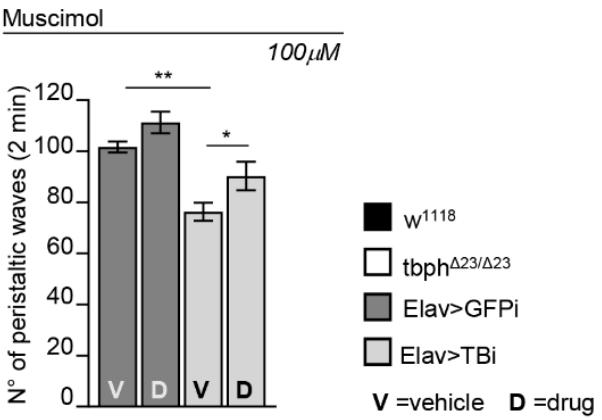

Figure 4. Pharmacological GABA stimulation ameliorates the motility defects in TBPH dysfunction.

A Peristaltic larval waves of third instar larvae of $\mathrm{w}^{1118}$ (black columns) and tbph ${ }^{\Delta 23 / \Delta 23}$ (white columns) fed with $200 \mu \mathrm{M}$ of Nipecotic Acid (D) and vehicle only (V). B Peristaltic larval waves of third instar larvae of Elav>GFPi (w,UAS-Dicer/+; tbph $\left.{ }^{\Delta 23}, e l a v-G A L 4 / U A S-G F P-I R\right)$ (dark gray columns) and Elav>TBi (w,UAS-Dicer/+; tbph ${ }^{\Delta 23}$, elav-GAL4/+;UAS-TBPH-IR/+) (light gray columns) fed with $200 \mu \mathrm{M}$ of Nipecotic Acid (D) and vehicle only (V). C Peristaltic larval waves of third instar larvae of Elav>GFPi (w,UAS-Dicer/+; tbph ${ }^{\Delta 23}, e l a v-$ GAL4/UAS-GFP-IR) (dark gray columns) and Elav>TBi (w,UAS-Dicer/+; tbph ${ }^{\Delta 23}$,elav-GAL4/+;UAS-TBPH-IR/+) (light gray columns) fed with $100 \mu \mathrm{M}$ of Muscimol (D) and vehicle only (V). $\mathrm{n}=20, * \mathrm{p}<0.05$, **p<0.01, ***p<0.001, calculated by one-way ANOVA. Error bars SEM.

\section{CONCLUSIONS}

Alterations in GABA neurotransmission were previously described in patients suffering from Alzheimer's disease (Govindpani et al., 2017), Parkinson's disease (Błaszczyk, 2016) and related neurodegenerative process including ALS (Foerster et al., 2013; Kim and Yoon, 2017). Nevertheless, the role of GABA in TDP-43 pathology was not clarified. In that respect we found that TBPH, the TDP-43 conserved protein in Drosophila, was required to maintain the correct intracellular levels of GABA. Regarding the molecular mechanisms involve, we discovered that $\mathrm{TBPH}$ regulates the expression levels of GAD1, the enzyme required to sustain GABA neurotransmitter expression, through the binding and processing of GAD1 mRNA (see also Romano et.al 2018). In addition, we observed that the pharmacological potentiation of GABA signaling with nipecotic acid, an inhibitor of GABA uptake, was able to significantly revert the locomotive defects observed in TBPH null flies. Altogether, the results reveal a novel molecular mechanism behind TDP-43-derived pathologies and put forward a potential pharmacological approach to compensate neurotransmitter balance defects in ALS affected individuals.

\section{DATA AVAILABILITY}

The datasets generated during and/or analyzed during the current study are available from the corresponding author on reasonable request.

\section{ACKNOWLEDGEMENTS}

We thank the Bloomington Stock Centre and Developmental Study Hybridoma Bank for stocks and reagents. 
bioRxiv preprint doi: https://doi.org/10.1101/2021.04.16.440162; this version posted April 16, 2021. The copyright holder for this preprint (which was not certified by peer review) is the author/funder, who has granted bioRxiv a license to display the preprint in perpetuity. It is made available under aCC-BY-NC-ND 4.0 International license.

Conflict of Interest statement. None declared

\section{REFERENCES}

Amador-Ortiz, C., Lin, W.-L., Ahmed, Z., Personett, D., Davies, P., Duara, R., Graff-Radford, N.R., Hutton, M.L., Dickson, D.W., 2007. TDP-43 immunoreactivity in hippocampal sclerosis and Alzheimer's disease. Ann. Neurol. 61, 435-445. https://doi.org/10.1002/ana.21154

Arai, T., Hasegawa, M., Akiyama, H., Ikeda, K., Nonaka, T., Mori, H., Mann, D., Tsuchiya, K., Yoshida, M., Hashizume, Y., Oda, T., 2006. TDP-43 is a component of ubiquitin-positive tau-negative inclusions in frontotemporal lobar degeneration and amyotrophic lateral sclerosis. Biochem. Biophys. Res. Commun. 351, 602-611. https://doi.org/10.1016/j.bbrc.2006.10.093

Błaszczyk, J.W., 2016. Parkinson's Disease and Neurodegeneration: GABA-Collapse Hypothesis. Front. Neurosci. 10. https://doi.org/10.3389/fnins.2016.00269

Buckingham, S.D., Hosie, A.M., Roush, R.L., Sattelle, D.B., 1994. Actions of agonists and convulsant antagonists on a Drosophila melanogaster GABA receptor $(\mathrm{Rdl})$ homo-oligomer expressed in Xenopus oocytes. Neurosci. Lett. 181, 137-140. https://doi.org/10.1016/0304-3940(94)90578-9

Cook, C., Zhang, Y.-J., Xu, Y., Dickson, D.W., Petrucelli, L., 2008. TDP-43 in Neurodegenerative Disorders. Expert Opin. Biol. Ther. 8, 969-978. https://doi.org/10.1517/14712598.8.7.969

de Boer, E.M.J., Orie, V.K., Williams, T., Baker, M.R., De Oliveira, H.M., Polvikoski, T., Silsby, M., Menon, P., van den Bos, M., Halliday, G.M., van den Berg, L.H., Van Den Bosch, L., van Damme, P., Kiernan, M., van Es, M.A., Vucic, S., 2021. TDP-43 proteinopathies: a new wave of neurodegenerative diseases. J. Neurol. Neurosurg. Psychiatry 92, 86-95. https://doi.org/10.1136/jnnp-2020-322983

Fei, H., Chow, D.M., Chen, A., Romero-Calderón, R., Ong, W.S., Ackerson, L.C., Maidment, N.T., Simpson, J.H., Frye, M.A., Krantz, D.E., 2010. Mutation of the Drosophila vesicular GABA transporter disrupts visual figure detection. J. Exp. Biol. 213, 1717-1730. https://doi.org/10.1242/jeb.036053

Feiguin, F., Godena, V.K., Romano, G., D’Ambrogio, A., Klima, R., Baralle, F.E., 2009. Depletion of TDP-43 affects Drosophila motoneurons terminal synapsis and locomotive behavior. FEBS Lett. 583, 15861592. https://doi.org/10.1016/j.febslet.2009.04.019

Ffrench-Constant, R.H., Mortlock, D.P., Shaffer, C.D., MacIntyre, R.J., Roush, R.T., 1991. Molecular cloning and transformation of cyclodiene resistance in Drosophila: an invertebrate gamma-aminobutyric acid subtype A receptor locus. Proc. Natl. Acad. Sci. 88, 7209-7213. https://doi.org/10.1073/pnas.88.16.7209

Foerster, B.R., Pomper, M.G., Callaghan, B.C., Petrou, M., Edden, R.A.E., Mohamed, M.A., Welsh, R.C., Carlos, R.C., Barker, P.B., Feldman, E.L., 2013. 3T MR Spectroscopy Reveals an Imbalance between Excitatory and Inhibitory Neurotransmitters in Amyotrophic Lateral Sclerosis. JAMA Neurol. 70, 1009-1016. https://doi.org/10.1001/jamaneurol.2013.234

Foran, E., Trotti, D., 2009. Glutamate Transporters and the Excitotoxic Path to Motor Neuron Degeneration in Amyotrophic Lateral Sclerosis. Antioxid. Redox Signal. 11, 1587-1602. https://doi.org/10.1089/ars.2009.2444

Gasnier, B., 2004. The SLC32 transporter, a key protein for the synaptic release of inhibitory amino acids. Pflüg. Arch. 447, 756-759. https://doi.org/10.1007/s00424-003-1091-2

Geser, F., Martinez-Lage, M., Kwong, L.K., Lee, V.M.-Y., Trojanowski, J.Q., 2009. Amyotrophic lateral sclerosis, frontotemporal dementia and beyond: the TDP-43 diseases. J. Neurol. 256, 1205-1214. https://doi.org/10.1007/s00415-009-5069-7

Gisselmann, G., Plonka, J., Pusch, H., Hatt, H., 2004. Drosophila melanogaster GRD and LCCH3 subunits form heteromultimeric GABA-gated cation channels. Br. J. Pharmacol. 142, 409-413. https://doi.org/10.1038/sj.bjp.0705818

Govindpani, K., Calvo-Flores Guzmán, B., Vinnakota, C., Waldvogel, H.J., Faull, R.L., Kwakowsky, A., 2017. Towards a Better Understanding of GABAergic Remodeling in Alzheimer's Disease. Int. J. Mol. Sci. 18. https://doi.org/10.3390/ijms18081813

Harvey, R.J., Schmitt, B., Hermans-Borgmeyer, I., Gundelfinger, E.D., Betz, H., Darlison, M.G., 1994. Sequence of a Drosophila ligand-gated ion-channel polypeptide with an unusual amino-terminal extracellular domain. J. Neurochem. 62, 2480-2483. https://doi.org/10.1046/j.14714159.1994.62062480.x 
bioRxiv preprint doi: https://doi.org/10.1101/2021.04.16.440162; this version posted April 16, 2021. The copyright holder for this preprint (which was not certified by peer review) is the author/funder, who has granted bioRxiv a license to display the preprint in perpetuity. It is made available under aCC-BY-NC-ND 4.0 International license.

Henderson, J.E., Soderlund, D.M., Knipple, D.C., 1993. Characterization of a putative gamma-aminobutyric acid (GABA) receptor beta subunit gene from Drosophila melanogaster. Biochem. Biophys. Res. Commun. 193, 474-482. https://doi.org/10.1006/bbrc.1993.1648

Higashi, S., Iseki, E., Yamamoto, R., Minegishi, M., Hino, H., Fujisawa, K., Togo, T., Katsuse, O., Uchikado, H., Furukawa, Y., Kosaka, K., Arai, H., 2007. Concurrence of TDP-43, tau and $\alpha$-synuclein pathology in brains of Alzheimer's disease and dementia with Lewy bodies. Brain Res. 1184, 284-294. https://doi.org/10.1016/j.brainres.2007.09.048

Josephs, K.A., Murray, M.E., Whitwell, J.L., Parisi, J.E., Petrucelli, L., Jack, C.R., Petersen, R.C., Dickson, D.W., 2014. Staging TDP-43 pathology in Alzheimer's disease. Acta Neuropathol. (Berl.) 127, 441450. https://doi.org/10.1007/s00401-013-1211-9

Kim, Y.S., Yoon, B.-E., 2017. Altered GABAergic Signaling in Brain Disease at Various Stages of Life. Exp. Neurobiol. 26, 122-131. https://doi.org/10.5607/en.2017.26.3.122

Mezler, M., Müller, T., Raming, K., 2001. Cloning and functional expression of GABAB receptors from Drosophila. Eur. J. Neurosci. 13, 477-486. https://doi.org/https://doi.org/10.1046/j.14609568.2001.01410.x

Neumann, M., Sampathu, D.M., Kwong, L.K., Truax, A.C., Micsenyi, M.C., Chou, T.T., Bruce, J., Schuck, T., Grossman, M., Clark, C.M., McCluskey, L.F., Miller, B.L., Masliah, E., Mackenzie, I.R., Feldman, H., Feiden, W., Kretzschmar, H.A., Trojanowski, J.Q., Lee, V.M.-Y., 2006. Ubiquitinated TDP-43 in frontotemporal lobar degeneration and amyotrophic lateral sclerosis. Science 314, 130-133. https://doi.org/10.1126/science. 1134108

Owens, D.F., Kriegstein, A.R., 2002. Is there more to GABA than synaptic inhibition? Nat. Rev. Neurosci. 3, 715-727. https://doi.org/10.1038/nrn919

Romano, G., Holodkov, N., Klima, R., Grilli, F., Guarnaccia, C., Nizzardo, M., Rizzo, F., Garcia, R., Feiguin, F., 2018. Downregulation of glutamic acid decarboxylase in Drosophila TDP-43-null brains provokes paralysis by affecting the organization of the neuromuscular synapses. Sci. Rep. 8, 1809. https://doi.org/10.1038/s41598-018-19802-3

Romano, G., Klima, R., Buratti, E., Verstreken, P., Baralle, F.E., Feiguin, F., 2014. Chronological requirements of TDP-43 function in synaptic organization and locomotive control. Neurobiol. Dis. https://doi.org/10.1016/j.nbd.2014.07.007

Schwab, C., Arai, T., Hasegawa, M., Yu, S., McGeer, P.L., 2008. Colocalization of Transactivation-Responsive DNA-Binding Protein 43 and Huntingtin in Inclusions of Huntington Disease. J. Neuropathol. Exp. Neurol. 67, 1159-1165. https://doi.org/10.1097/NEN.0b013e31818e8951

Trotti, D., Aoki, M., Pasinelli, P., Berger, U.V., Danbolt, N.C., Brown, R.H., Hediger, M.A., 2001. Amyotrophic Lateral Sclerosis-linked Glutamate Transporter Mutant Has Impaired Glutamate Clearance Capacity. J. Biol. Chem. 276, 576-582. https://doi.org/10.1074/jbc.M003779200

Van Den Bosch, L., Van Damme, P., Bogaert, E., Robberecht, W., 2006. The role of excitotoxicity in the pathogenesis of amyotrophic lateral sclerosis. Biochim. Biophys. Acta 1762, 1068-1082. https://doi.org/10.1016/j.bbadis.2006.05.002

\section{Supplementary Material}
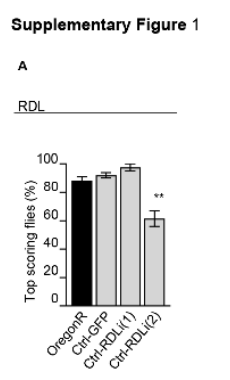

C

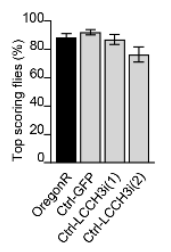

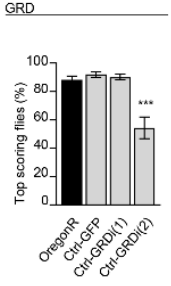
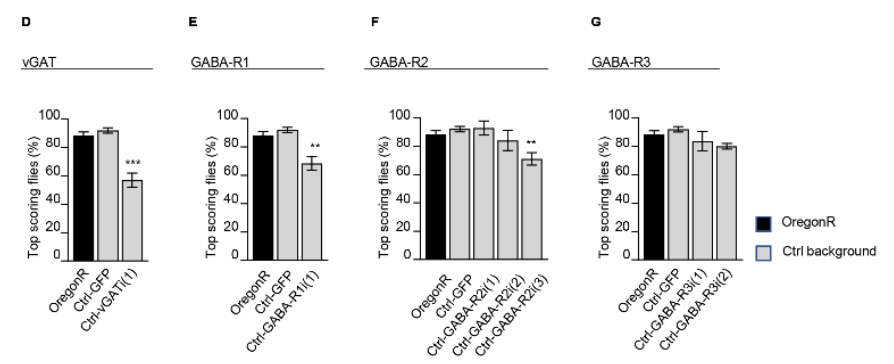

Supplementary Figure 1. Silencing of GABA receptors in wild type background. A-G Climbing assay of 4 days adult flies of OregonR (black column), Ctrl-GFP (tbph ${ }^{\Delta 23}$, elav-GAL4/UAS-GFP;UAS-Dicer/+) and Ctrl-GABA receptor name (tbph ${ }^{\Delta 23}$, elav-GAL4/UAS-GABAreceptor IR;UAS-Dicer/+). In A RDL-IR line (1)= \#41101, line (2) \#100429; in B LCCH3-IR line (1) \#37409, line (2) \#109606; in C GRD- 
bioRxiv preprint doi: https://doi.org/10.1101/2021.04.16.440162; this version posted April 16, 2021. The copyright holder for this preprint (which was not certified by peer review) is the author/funder, who has granted bioRxiv a license to display the preprint in perpetuity. It is made available under aCC-BY-NC-ND 4.0 International license.

IR line (1) \#38384, line (2) \#58175; in D vGAT-IR line (1) \#45916; in $\mathbf{E} \mathrm{GABA}_{\mathrm{B}}$ receptor type 1 line (1) \#101440; in $\mathbf{F}$ GABA $\mathrm{B}$ receptor type 2 line (1) \#1784, line (2) \#1785, line (3) \#110268; in $\mathbf{G ~ G A B A}_{B}$ receptor type 3 line (1) \#50622, line (2) \#108036. The total number of tested animals per genotype was $>50 . * * \mathrm{p}<0.01, * * * \mathrm{p}<0.001$; calculated by one-way ANOVA. Error bars SEM. 